\title{
The Machinery of Planning in the United Arab Republic
}

\author{
by \\ Nimrod RAPHAELI, \\ The University of Michigan. \\ UDC 338.984 .3 (62)
}

The first attempt to set up a planning unit in Egypt took place a few months after the military junta had seized power. In October 1952, the Permanent Council for the Development of National Production (or Permanent Production Council) was formed as an independent agency of the Cabinet, with the following functions:

1. To examine and recommend projects of development in the fields of irrigation, land reclamation, electrification, mining, and industrialization and to examine the means of financing these projects, both internally and externally;

2. To present to the Cabinet, within a year of its inception, an integrated program of national economic development to be carried out over three years; and pending the completion of the plan, to present, as deemed necessary, well conceived projects for immediate execution; and

3. To proceed with an early examination of the possibilities of increasing the local supply of food grains, petroleum, sugar, animal products, and fertilizers, with a view to overcoming existing bottlenecks.

The Council, presided over by the Prime Minister, could carry out certain schemes and launch pilot-plants, to be administered directly under its own supervision, or under supervision delegated to others. It was also required to follow up the execution of approved schemes.

Failing to perceive development as an integrated and coordinated activity demanding more than a random performance, however, the Council became concerned mainly with single projects or, at best, with groups of projects. "Its look", says Dr. Ibrahim Abdel-Rahman, Director General of the Institute of National Planning, "was nearer to that of a private business agency endowed with public authority (1)"

(1) Planning for Balanced Social and Economic Dev. elopment, Cairo, Institute of National Planning, memo No. 63, 1961, p. 15.
Then, shortly after its establishment, the Council was dispersed, and until 1955, the Egyptian Government experimented with various planning organizations, such as the Higher Organization for Coordination and Planning (1952-1954), an advisory committee with no authority to make decisions binding upon the individual ministers, and the Permanent Council of Public Services (1953. 1955) (2).

These planning units were perhaps symptomatic of the political instability and power struggle characteristic of the early years of the military regime in Egypt. Administratively, the units were based on two principles: (a) Sectoral planning, and (b) Unity between planning and execution.

Due to Egypt's limited resources and high rate of population growth, and, above all, due to Egypt's desire to build the High Dam of Aswan (which became identified with the political, economic, and social aspirations of the regime), it was decided, for the first time, to set up a comprehensive planning agency. Therefore, in March 1955, the National Planning Committee was established.

\section{National Planning Committee}

The Committee was born during a period of grave crisis in Egyptian history, emanating from the failure to materialize the loan from the United States for the building of the Dam, from the nationalization of the Suez Canal, and from the hostilities that followed. For two years, the country's leadership was almost exclusively concerned with foreign policy and defense, and there was little accomplished in the vital area of economic development. It was only in January 1958, with the final stabilization of the regime under the uncontested leadership of President Nasser, that

(2) Each ministry was instructed to form a planning committee composed of the senior staff members of the ministry, while individual ministers remained free to carry the proposals of their own planning committee directly to the Council of Ministers. 
planning was acted upon rather seriously, and the final foundations of permanent planning apparatus were laid. It is the critical analysis of this apparatus that concerns us most.

The new planning organization was composed of a Higher Council, under the chairmanship of the President of the Republic, and a National Planning Committee (NPC), under the chairmanship of the Minister of National Planning.

The entire body of ministers and deputy ministers forms the Higher Council which defines the general objectives of the development program and examines the draft plans prepared by the NPC.

In preparing the draft comprehensive plan the NPC defines in particular:

1. Financial resources.

2. Allocation of material resources to different uses.

3. Methods of finance and credit in the public and private sectors.

4. Foreign exchange situation and balance of payment.

5. Projects and programs of investment in all of the economic and social sectors.

6. Vocational and technical training and human resources.

7. Procedures and agencies of the coordination of execution and development.

8. Follow-up of the plan.

9. Statistical activities in the country (3).

The principle of separation between planning and execution is maintained. Not only has the central planning staff no executive responsibility, but the whole area of execution is decentralized functionally and territorially. On the functional level, ministries, departments, and public enterprises are responsible, each in its field of work, for executing the projects and realizing the targets of the Five-Year Plan. Territorially, the country is divided into 25 Governorates (mobafazat) each headed by a Governor with the rank of deputy minister. Each one of the functional and territorial units has a planning committee which initiates specific projects to be examined later by the NPC in accordance with the national plan (4). In other words, these local bodies do not, in fact, enjoy much authority. They are mere transmission belts carrying orders from central planning authorities and feeding up some technical details. Even the director of the Institute of National

(3) Abdel-Rahman, $O p$. cit., pp. 34-35.

(4) Ibrahim Abdel-Rahman and M. Tewfiq Ramzi, The Organizational and Administrative Aspects of Development Planning, Cairo, Institute of National Planning, 1961, p. 17.
Planning could not delineate their activities more precisely than to say they rest " in the fields of social and infrastructural services (5) ". Unofficially, as one informant pointed out to this author, these local bodies attempt to "popularize" planning, that is, to bring the objectives of the plan closer to the people.

\section{The Operation of the Planning Unit}

In spite of the organizational paraphernalia we have just described, authority still remains in the hands of the President of the Republic. As AbdelRahman pointed out :

Preliminary directions as well as the final adoption of the plan are in the hands of the President himself, assisted by a ministerial committee for planning (6).

It is commonly agreed that chairmanship of the planning unit by the chief executive of any country imparts a great measure of authority and prestige to the actions of the unit, and assures the fastest possible response from other agencies. This is particularly true in Egypt where the chief executive, President Nasser, enjoys supreme authority over his countrymen. But while authoritative leadership in a country such as Egypt is a boon, it becomes as well a bogie, for precisely because of this kind of leadership, criticism cannot be voiced and shortcomings are concealed. Against this background, the work done by Professors Gulick and Pollock of the United States becomes especially valuable, as it illuminates some aspects of the planning machinery hitherto curtailed from all outside the small ruling elite in Egypt (7).

The criticism by Gulick and Pollock is most severe. For example, they say that " the U.A.R. now has a first-rate plan and planning system on paper " (8), and then they cite the folowing "points of serious failure", in the present organization and procedures of NPC:

... up till now the National Plan is insufficiently an organic part of government or administration. Until very recently, planning has been a superficially added activity of government, much as the automobile starter was first introduced as a special gadget, or " extra "...

... planning is now too exclusively a central-govern.

(5) Ibrahim Abdel-Rahman, Organization Arrangements for National Planning in the UAR, presented at a UN Conference on the Application of Science and Technology for the Benefit of the Less Developed Areas, E/Conf. 39/H/53, 19 October 1962, p. 7.

(6) Ibid., p. 7.

(7) Luther Gulick and James K. Pollock, Government Re-organization in the United Arab Republic (A Report Submitted to the Central Committee for the Re-organization of the Machinery of Government), Cairo, 1962. My thanks go to Professor Pollock for making the report available to me.

(8) Ibid., p. 31. 
ment, ivory tower operation. ... the execution of the Plan must not rely solely on central direction and supervision; it must draw in those who do the work, in office, plant, shop and local government.

Only a few officials and intellectuals now know what the Plan is or pay any attention to its provision. There is as yet no adequate system for translating Plan decisions into accountable orders issued to operating agencies (9).

The major reason for the unsatisfactory status of the planning effort, according to the authors, ... arises not from the planning machinery itself, but from the administration habits of the total government, and from the lack of administrative force and orderliness which characterises governmental management as such.

The authors further point out that

The present habits of management are not geared to planning. The men who run the agencies, and their top civil servants, never lived in a world of comprehensive social and economic planning before. The whole psychology of the thing is new to them. Such planning was never part of their work habits. Even the best men have been working to get their own job done well, they have never had time to think of whether they fit into a carefully designed comprehensive and coordinating national economic and social effort (10).

The authors also observed that :

There appeats to be an excessive system of controls which inhibits the exercise of prompt and effective action (11).

Prior to the submitting of Gulick and Pollock's report, and in order to overcome these and other obstacles, sixty joint committees were formed of senior officers of the NPC and executives from ministries and public agencies. A further remedial step was the establishment, early in 1959, of a planning office in every ministry and public agency, to be attached to the office of the minister or the head of the agency. "The members of each office", a former staff member of the planning organization states

[were] chosen and appointed by the Minister or the Agency Head. ... there was no sound basis for the appointment of these members as Planning Office members. Most of them lacked the necessary knowledge and skill to perform their duties. One year later, it was found that the formal link between the Planning offices and the National Planning staff was not clear, and, to many authorities, it proved unworkable (12).

\section{SUMMARY}

As we sum up our brief discussion of the Egyptian planning machinery, we are forced to conclude that the machinery has not performed satisfactorily in spite of the strong political support given to it by the top political leadership of the country. A partial answer may be provided in the fact that the departmental coordination and cooperation so necessary to carrying out the provision of the plan seem to be ineffective. There appears to be a failure to weave national planning machinery into the fabric of government. As a result, the "Top Command" make the decisions and issue the commands " but somewhere the battle is lost. That which was decided fails to happen. Instead of a single national plan, each agency still tends to go off on its own, with a different set of private objectives (13) ". Although the ruling group and most of the civil servants in policymaking positions seem to be committed to the objectives of development planning, such conscientiousness has not penetrated sufficiently into the middle and lower ranks of the service where lies the responsibility for the detailed execution of the plan.
(9) Ibid., pp. 30-31.

(10) Ibid., p. 32.

(11) Ibid., p. 8.
(12) Salah A. Gohar, The Administrative Organiz ation of Developing Planning, MPA thesis, The University of Michigan, Institute of Public Administration, Ann Arbor, 1962, p. 8.

(13) Gulick and Pollock, Op. cit., pp. 6-7. 